\title{
COMPARISON OF NUCLEOTIDE SEQUENCES OF THE RPLJ LEADER IN ENTEROBACTERIA
}

Determination of primary structure and comparison of the mRNA secondary structure in the rplJL lider was carried out for five species of Enterobacteria. The highly conserved structural organisation was found.

Gene expression in the rplJL operon encoding ribosomal proteins $L 10$ and $L 12$ of $E$. coli is regulated autogenously at the level of translation by the feedback mechanism $[1,2]$. The regulatory protein ( $L 1 O$ or $L 1 O$ L12 complex) binds the rplJ leader about 150 nucleotides upstream of the start codon and results in translational block [3], hypothesized to occur because of mRNA secondary structure transition to a form in which the ribosome binding site is sequestered [3]. We observed a negative effect, typical for the feedback regulating proteins, when the $E$. coli L1O was overproduced in Salmonella [4], Klebsiella [5] and Citrobacter [6]. We reasoned that the ability of the $E$. coli $L 10$ to regulate expression of heterologous $r p l J L$ operons was provided by the highly conserved structure of the protein binding site as well as of whole the rplJ leader. Comparison of the rpll leader sequences from five species of Enterobacteria was aimed to find structural similarities of potential functional importance.

Fragments containing the rplJ $5^{\prime}$-terminal portion were isolated from the chromosomal DNA of Citrobacter freundii and Serratia marcescens by PCR technique [7] and cloned in pUC plasmid [8]. Sequencing was performed by the procedure [9]. Two recombinant phages kindly provided by $M$. Nomura, M13 018157 (with the rplK'AJL rpoBC' DNA fragment from $P$. vulgaris) and $M 13018155$ (with the rplK'AJL' fragment from $\mathrm{S}$. marcescens), were used to subclone and sequence the respective rplJ leaders. Comparison of the determined rplJ leader sequences of $C$. freundii, $P$. vulgaris and $S$. marcescens with those of $E$. coli $[10]$ and S. typhimurium [11], shown in Fig. 1., revealed the regions with highly and completely conserved structure. The E. coli rplJ leader contains five double-stranded regions (I-V) [12]. The mRNA secondary structure predicted for the sequenced leaders showed that similarly to E. coli five regions of base-pairing are typical also for rplJ leaders in other Enterobacteria (Fig. 2). Nucleotides in region IV ascribed to $L 10$ binding site [13-15] are completely conserved. Another structural similarity shared by all compared species is the GNAA tetra loop in stem-loop siructure IV. Noteworthy, the GNAA and UNCG tetraloops can confer unusual stability to the stem [16]. The number of conserved base-pairings at foundations of all five stems is equal within all species. The conserved length of the single-stranded regions between stems IV and III (consisting of 3 nucleotides) and between stems II and I (consisting of 9 nucleotides) may be of structural importance. The single stranded region between stems III and IV, comprising 7 nucleotides in all but the E. coli leader, may have a similar function. In vitro structural analysis [12] failed to proove the conformational switch in the $E$. coli rplJ leader proposed to cause translational block [12]. Interestingly, that sequences presumed 

$1 \because 1$
$3: 2,40)$
1500
$=:=\pi=1530$
1600

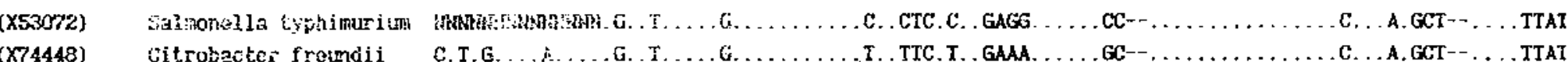

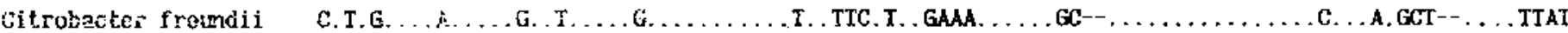

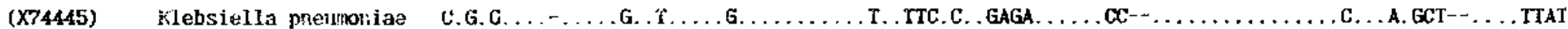

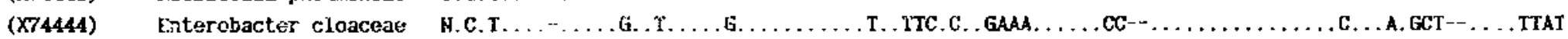

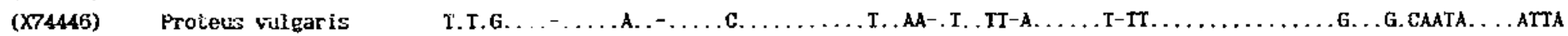

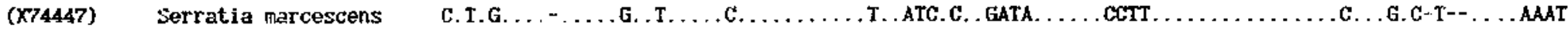

C G CCTA ICCAg CC CCGTC AMGACCGCAGG GT G AA CTTAAT CĆTGCGTAGACGgTGA AGA C AAGA

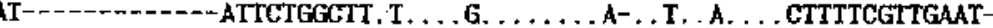
-ACTCTGGCTT. T. . . G. . . . . . . A- . A. . A . . . CTTCCCGTTGGGT- TG. ..........

TC. A. AGCA , AGGCT, T. . CA, AG. .

TAAAT G. A. . A. .......GT. T. . . . TATACCATTGIGGTMATA.... T . . . .

IATTCT- - -

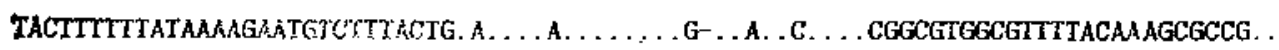
G TCI CTCACCGT TT AG CGST III . $1-\cdots-\cdots+-2$ II AGTGA GTGAGT CG G T

C. CT. --

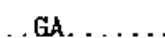

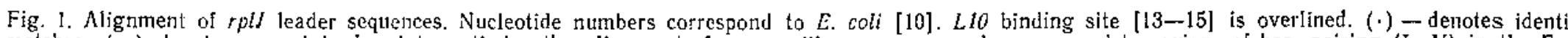
matches; (-) denotes gaps introduced to optimize the alignment. Arrows with roman numerals correspond to regions of base-pairing (I-V) in the $E$,

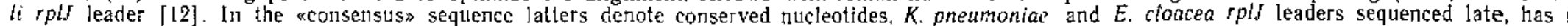
been discussed but completely support consensus mRNA secondary structure proposed. 
necessary for the switch are completely conserved in all the leaders, as if pointing out another possible functional role. Nucleotides C1548, G1590, G1594, C1634 and G1640 were shown to be important for the functional role of the $E$. coli leader and are conserved among the analyzed species. Also concerved are A1571 and Al572 in the bulge loop of region

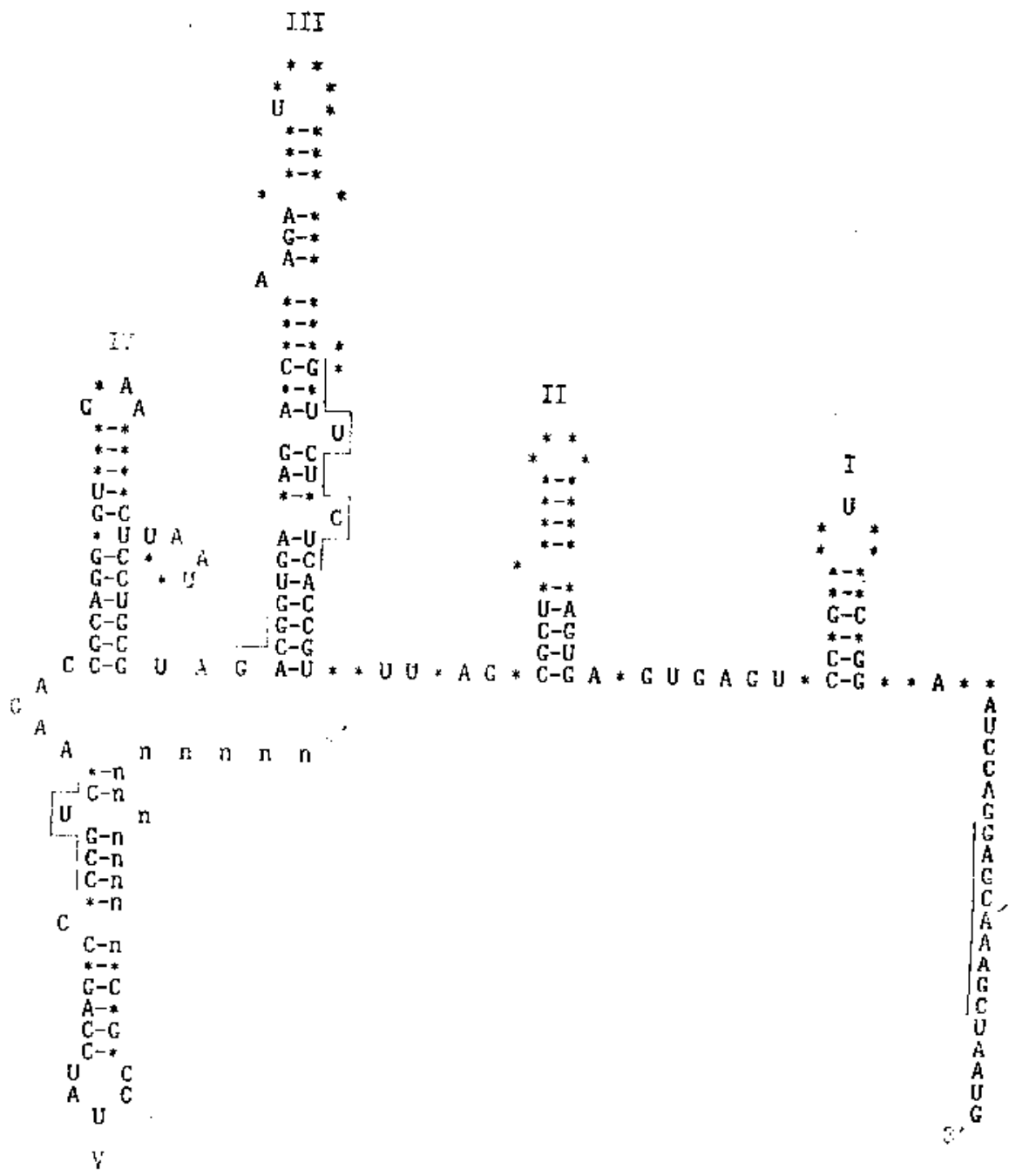

Fig. 2. A consensus mRNA secondary structure of enterobacteriai rpls leader based on the secondary siructure of the $E$. coli leader mRNA [12] and alignment of five entero. bacterial leader sequences. Latters denote conserved nucleotides. (*) - denote variable nucleotides, $n$ - not determined. Sequences presumed to provide structure transition of the $E$. coli $\mathrm{rpl}$ leader to the untranslatable form [3] are marked

IV. In the E. coli leader these two bases are strongly protected by $L 10$ LI2 complex [12]. Besides the general similarity forming the ground for the consensus secondary structure (Fig. 2) rightful for all compared rpIJ leaders, additional similarities can be found within two subgroups: Escherichia, Salmonella, Citrobacter and Proteus, Serratia.

In E. coli translation regulation of $L 10-L 12 \mathrm{mRNA}$ by the feedback mechanisms requires at least two structural elements. The rplJ leader region binds the regulatory protein which results in translational block. Repression of $L 12$ translation is achieved via the long-range interaction between the $L 1 O$ and $L I 2$ cistrons [17]. Comparison of the sequenced $5^{\prime}$ portions of the rplJ coding sequences (results not shown) revealed the 
complete conservation of the rplJ sequence necessary for translational coupling. Therefore, phylogenetic comparison lends evidence for similarity of structural requisites of the feedback regulation mechanism in Enterobacteria.

\section{О. М. Живолуп, I. В. Қрупська, Т. М. Лясковський, Є. Б. Патон}

\section{ПОРІВНЯННЯ НУКЛЕОТИДНИХ ПОСЛІДОВНОСТЕИ ЛІДЕРІВ ГPIJL OПЕPOHВB ЕНTEPOБАKTEPIY}

\section{Pез юм е}

Проведено визначення нуклеотндної послідовності та лорівняння структур лідерних областей rplJ оперонів п'яти ентеробактерій. Виявлено внсоку консервативність структурової організації.

\section{REFERENCES}

1. Lindaht L., Zengel J. $M$. Ribosomal genes in Escherichia coli // Ann. Rev. Genet.1986.-20, N 1.-P. 297-326.

2. Fiil N. P., Friesen J. D., Downing W. L., Dennis $P$. $P$. Post-transcriptional regulatory mutants in ribosomal protein-RNA polymerase operon of $E$. coli // Cell.$1980 .-19$, N 3.-P. 837-844.

3. Christensen T, Johnsen M, Fiil N. P., Friesen J. D. RNA secondary structure and translation inhibition: analysis of mutants in the rpl/ leader // EMBO J.- 1984.3. N 7.- P. 1609-1612.

4. Paton E. B., Woodmaska M. I., Kroupskaya $I$. V., et al. Evidence for the ability of L1O ribosomal proteins of Salmonella typhimurium and Klebsiella pneumoniae to regulate rplJL genes expression in $E$. coli // FEBS Lett. - 1990._-265, N 1, 2.P. $129-132$.

5. Zhyvoloup A. N, Paton E. B. Ability of the geteralogous regulation of the rplJL operon genes expression in Klebsiella pneumoniae by protein L1O of E. coli // Biopolymers and Cell (Russ) - $1992 .-8, N 3 .-$ P. $51-53$.

6. Zhyooloup A. N., Paton E. B. Lio protein of E. coli is regulating gene expression in the rpilL operon Citrobacter freundii// Ibid.- $1993 .-9, \mathrm{~N} 6 .-\mathrm{P} .90-92$.

7. Zhou Y., Zhang X., Ebright R. H. Random mutagenesis of gene-sized DNA molecules by use of PCR with Taq DNA polymerase // Nucl. Acids. Res. 1991_- 19. N 21 - P. 6052 .

8. Yanisch-Perron C., Vieira J., Messing J. Improved M13 phage cloning vectors and host strains: nucleotide sequence of $M 13, \mathrm{mp} 18$ and $p U C 19$ vectors $/ /$ Gene- -1985 . 33, N 1.-P. $103-119$.

9. Innis $M$. A., Myambo K. B., Gelfand D. H., Brow M. A. D. DNA sequencing with Thermus aquaticus DNA polymerase and direct sequencing of polymerase chain reaction-aniplified DNA // Proc. Nat. Acad. Sci. USA.- 1988.-85, N 27.P. 9436-9440.

10. Post L. E., Strycharz G. D., Nomura $M$. et at. Nucleotide sequence of ribosomal protein gene cluster adjacent to the gene for RNA polymerase stbunit B in Escherichia coli // Ibid. -1979.-76, N 1.-P. 1697-1701.

11. Zhyvoloup A. N., Woodmaska M. I., Kroupskaya I. V., Paton E. B. Nucleotide sequence of the rpllL operon and the deduced primary structure of the encoded $L 10$ and $L 7 / L 12$ proteins of $S$. typhimurium compared to that of $E$. coli // Nucl. Acids Res.- 1990.- 18, N 15.-P. 4620.

12. Climie S. C., Friesen J. D. In vivo and in vitro structural analysis of the rotJ mRNA leader of Escherichia coli // J. Biol, Chem.-1988.- 263, N 29.-P. 1616616175 .

13. Climie $S$. $C$, Friesen $I . D$. Feedback regulation of the rpl/-rpoBC ribosomal protein operon of Escherichia coli requires a region of mRNA secondary structure $/$ J. Mol. Biol.- 1987.- 198, N 3.- P. 371-381.

14. Draper $D$. $E$. How do proteins recognise specific RNA sites? New clues from autogenously regulated ribosomal proteins $/ /$ Trends in Bjochem. Sci.-1989.-14, N 8 - - P. $335-338$.

15. Lindahl L., Zengel $J$. $M$. Diverse mechanisms for regulating ribosomal protein synthesis in Escherichia coli // Progr. Nucl. Acids Res. and Mol. Biol.-1993.P. $1-61$

16. Varani $G$., Cheong $C$., Tinoco $I$. Structure of an unusually stable RNA hairpin // Biochemistry.- 1991.-30, N 13.- P. 3280-3289.

17. Petersen $C$. Long-range translation coupling in the rplJL-rpoBC operon of Escherichia coli // J. Mol. Biol.-1989.-206, N 1.-P. 323-332. 